THE COLLEGE OF MEDICINE, NEWCASTLEON-TYNE.

ADDRESS BY DR. HEATH.

THE winter gession of the University of Durham College of Medicine, Newcastle, was formally opened on the lst inst. in the library of the institution, on which occasion the prizes and scholarships were distributed to the winners thereof by the Marquis of Londonderry.

Dr. HEATH (the President)ioccupied the chair and delivered an address. After welcoming them most cordially to the thirty-ninth session of the College, he said that he had a report from their excellent secretary, Mr. Fox, showing that the number of students attending lectures, and also candidates going up for Durham degrees, had gone on progressively increasing since they entered that house two years ago. He had to announce that Mr. Stephen Scott of Harrogate, formerly of Newcastle, actuated by his love of science, his desire to further medical knowledge and to alleviate human suffering, had placed in their hands $£ 1000$, part of which at least, he hoped, would be handed over to some of the students, or to the author of the best essay upon an interesting and not uncommon disease. It would be interesting to them to know that the period of medical education had been extended from four to five years by the action of the General Medical Council. The Council was also deeply interested in that important subject, the prevention of disease, which was really the urgent and most pressing medical question of the day. Jealously watchful, he might say, that the education given to candidates in degrees or certificates for hygiene should be fair and genuine, they had now added to previous regulations a proviso that all candidates for degrees should spend six months in a laboratory, where they should obtain practical instruction in everything that pertained to hygiene and sanitary science, and also where they would learn something of the relations of the diseases of animals to the health of man. He felt that the College of Medicine would do wisely to recognise the feeling of the profession, and also of the general public, with regard to this subject. The University of Durham had quite recently undertaken to confer degrees in hygiene, and they were under the obligation to meet this enlightened action of the University of Durham by providing for candidates an effective and sufficient education. The best mode, he thought, of doing this would be to establish in the sanitary department of the College a laboratory of hygiene where students in sanitary science, and where candidates for degrees in hygiene, or others who from official position or taste would like to take up this subject, would be instructed; also where students would be taught to recognise the importance of tracing the origin-to follow out the whole life history-of those minute creatures who in the present day were considered to be the living causes of disease. Such a laboratory would not only be a benefit to the College itself, but a public benefit to the district. What, after all, could be of more overwhelming importance than the prevention of disease - that factor which of all others rendered life miserable, if it did not destroy it? He would read an extract to them from a speech of the Prince of Wales on the occasion of the opening of the Institute of Hygiene in London. The Prince of Wales said: "As one looks over our programme it is im. possible not to feel distress and even horror at the multi. tude of dangers to health in the midst of which we have to live. Some of these appear to be at present inevitable, but a great number may with certainty be averted." They had to remember that that was not from a doctor, but the head of this nation, the future king. He had not time to describe or even to enumerate the many diseases already swept away by appropriate measures. He would select one, and endeavour to illustrate how such a laboratory as he had described would prove useful, not only to that College, but to the district. He would take tuberculosis, and give the words of Burdon Sandersona Newcastle man. In opening a discussion on tuberculosis he said: "There is no disease, acute or chronic, so productive of human suffering or so destructive of human life." These were strong words, but he thought there was not a medical man in that room who would not endorse them as representing the simple truth. The seeds of tuberculosis might be found in divers places. They might enter the body by more than one route, but like other evil things they haunted dark and secret places. They found t for an absolute certainty that such infected milk would nfect children who partook of it. Now, how was this most disastrous infection to be prevented? Not by depriving. hildren of what was their natural and appropriate food, ut by rendering that food wholesome, and this could only done by inspection of milk, of dairies, of byres, of anghter-houses, and of meat generally. So as to be sure that no mistake might be made, they would require skilled experts. No such experts at present existed; they had to be taught. He felt sure that such a department of public ealth as that College was the very place where such instrucion should be given. It would have to be given, it would ave to be done, and this was the time to do it. $\mathrm{He}$ was told there were a great many difficulties in carrying hose ideas into practice. What they were doing in America with regard to the matter was this: they wished to sell their pigs' flesh to the Germans, but the latter would not take it unless they knew that it was sound and free from tuberculosis. So they had an army of 3000 inspectors in Chicago alone. What the Americans could do for their pigs. could we not do for our living children? They were sometimes told that they lived in a necessary struggle upon this earth with the forces of nature. Well, the forces of nature: were not always inimical to them. Life itself, indeed, might be said to be the result of the action of those forces. But the forces of disease were always hostile to them, and they courted the conflict. Now the power of disease-that mighty power--was based upon an army of innumerable microscopic units, invisible and intangible to their unassiated senses. If any of these effected an entrance into the human body, then a struggle took place within them. The issue was uncertain, but even if favourable, a struggle of that kind always left behind disastrous effects. But if they were able to grapple with those minute creatures in their own haunts and thus destroy them, the battle was fought outside the body. The struggle was then more favourable to them. And although the battle might be protracted, difficult, and arduous, nevertheless the issue was certain, and the victory belonged to man. And he would ask, was not the victory the purest under heaven that was waged with weapons no more deadly than the test tube and the microscope? It was not attended by bloodshed or by remorse. He should like to see prosperous, wealthy, and populous Newcastle take a foremost place in this battle, and he would like to see that College also take a foremost place in it, and both of them receive an honourable share of the glories of that victory.

\section{UNIVERSITY COLLEGE, LIVERPOOL.}

ADDRESS BY PROFESSOR NICHOL.

ON Oct. 3rd, after the distribution of medals, prizes, and certificates by Lord Derby, Professor Nichol delivered an address. He said that on being requested to open the ensuing session of that University, his sole difficulty was that of saying something both new and true. He had a special difficulty in the fact that since selecting a theme he bad found himself largely anticipated by two most. capable scholars-Professor Bradley and Mr. Churton Collins. With what these two gentlemen had said on the position of English literature in the curriculum of an English college he so wholly concurred that he could do little more than expand, illustrate, and accentuate some of: their views. That their university systems had been so frequently arraigned of late testified to the interest in education, which was the best feature of our time, as well as to the restlessness, which was its worst. The danger of organised training was rigidity-the hidebound sameness of pedantry on the one hand, and on the other of a. contracted utilitarianism. The former was the vice of old universities; the latter should be the bugbear of the new. A college set in the midst of a great. commercial society, to whose munificence it owed perhaps its establishment, must be jealous of its independence, nor over-grant the claims of those who, having helped to lay the keel of the ship, aspired to hold the helm. Let them devote themselves to what was nseful, but let them give a large meaning to the word, and include within it whatever pursuit opened out a new source of mental activity or tended to make them worthier students, more sympathetic teachers, better citizens, or in any of the relations of life wiser men. In this regard he need say nothing of the claims of physical science, mental philosophy, and 
little as to the languages and literatures of Greece and Rome. He had no sympathy with their disparagement. Every argument in favour of the study of language in general applied with double force to that of our own. The literature which it had ensbrined was the greatest and most varied of all modern literatures. It involved the knowledge of others sufficient to modify our own exclu. siveness. Like our commerce, it held out hands to half the nations. Itself of no mushroom growth, it had transcribed for our instruction-not always, indeed, in perfect style, but with material accuracy - the best wisdom of the older world. Matthew Arnold remarked, in one of those freaks of phrase which he was so constantly denouncing, and in which he so constantly indulged, that " the English zeal for education is that of a newly a wakened sinner." That was hardly fair to the memories of Alfred, Ascham, Bacon, Milton, and Knox. But it was quite fair as applied to the provision made in our universities for their higher study of our language and literature. He then proceeded to deal with Mr. Freeman's remark that he did not wish English literature to be recognised in any university curriculum ; first, because it was a subject which could not be tanght, and, second, because all attempts to teach it had been simply mischievous. The business of a university was, they were told, to teach a scholarly knowledge of languages, not their practical mastery. Facts might be taught, but the delicacies and - elegancies of literature could not be driven into any man. Freeman's whole argument was a sheaf of assump. tions so false, and of fallacies so shallow, that it were mere waste of time to discuss them if they were not living in an age in which "mere iteration" proceeding from any show of authority in politics or literature carried belief. "The first of these was the assumption that the whole duty - of a university was to set examination papers, and to cram, grind, drive, or hammer students into shape to answer them. Another false postulate was that there was no standard of taste-a presumption fatal to the idea of instruction in any art, refuted by the fact that when the mists of passing mannerisms and the frolics of fantastic schools had faded there emerged a substantial agreement on the merits of great works and authors. He would certainly advise anyone desiring to make literature the business of his life to make sure that he knew what he was undertaking, and to realise the risks he ran. M. Renan had said that no one had had the same advantages as the French Academy for fighting against the mischief of inferior literature, and Arnold had added that France would not tolerate such slovenly journeyman work as was to be found in our provincial and in all but the best of our London papers. T'he English universities should constitute the English Academy, but hitherto in this matter they had betrayed their trust, and handed over the artistic censorship of the press to the whims of the populace. The learned Professor, bidding truce to controversy, spoke of the study of literature as a comment on history and a lesson in life. Knowledge of the thought of other men was the surest means of lifting us out of the rut in which the subdivisions and details of our distrait activily would otherwise constrain us to move. He advised students in the study of literature to find out what they could do with a fair amount of work, and to do it. $A$ general survey of the stream of literature bade them believe in the ultimate progression-not, indeed, of individual genius, but of collective wisdom. The same survey also compelled them to be tolerant of differences of opinion, and, what was in the long run more difficult, differences of character.

\section{THE SANITARY ASSOCIATION OF SCOTLAND.}

THE seventeenth annual Cungress of this Association was held in Edinburgh on Wednesday and Thursday, the 23rd and 24th of September. Dr. Farquharson, M.P., on Wcdnesday presided, and the meetings were held in the Council Chambers. The proceedings commenced with the holding of the annual business meeting, at which the report for the year and other matters were considered. Thereafter Dr. Farquharson proceeded to deliver his presidential address on a "Model Hygienic State, or a Glance at the Sanitation of the Fature." He referred to the mecessity of more organised attention being given by Parliament to hygienic matters by the appointment of a
Minister of Public Health. While acknowledging the great advances made during the past fifty years in sanita. tion, he doubted whether we had profited as much as we might by the experience of the past. Things were no doubt better than they were. County Councils had introduced a better segulated hygienic machinery into localities, and had, in Scotland at all events, been compelled, by combination or otherwise, to appoint scientific pro. fessional advisers in every district. He thought, however, that the salaries given to the medical oflicers were too small for the class of men who were required. He also $\mathrm{d}$ welo upon the recessity of a closer union between head. quarters and the various branches of the Public Health service throughout the country. The medical officer of health, whether working patiently on in some remote district or fighting the battle against a dreadful disease in a large town, would derive help and stimulus from an occasional visit to headquarters, or from a call from a peripatetic inspector from a central office; and those who formed the organising and initiating brain, to which thes e cifferent cords converged, would equally depend for their plans of coördination and hygienic campaign on the reports they received, and the comments and reflections which various acute minds, working locally, had to make on the facts coming under their observation. The central authority, as at present constituted, was not able to do this, nor was it likely to be so long as it remained only a bit of another department. Agriculture had been separated from other things, and was now under a separate board, and what had been done for it ought to be done for the public bealth. It should be handed over to a distinct and separate department, whose chief would have a seat in the House, and even in the Cabinet, and have supreme jurisdiction over an extensive and well-organised intelligence bureau. Nothing could be better of its kind than the work embodied in the yearly reports from Dr. Buchanan's office Conceived in the highest scientific spirit, it was carried out with a zeal and skill and patience which were the admiration of hygienic authorities all over the world. But there was far too little of it. What they required was an army of experts and inspectors who were not obliged to wait for orders from a bureaucratic network of red tape before they could set their machinery in motion, but who were always working well ahead, investigating causes, devising means for preventing, and giving active and practical help to every line of research which had any bearing on their proper lines of progress. The rate of scientific movement was at present enormously rapid, but it was almost exclusively worked by private persons, and although no one would seek to limit or discourage individual effort, he did hold that Government should do more to help those who were thus so effectually helping themselves and others. A strong department such as he had indicated would not only initiate and carry out independent lines of research, but would aid and subsidise those who were proceeding in parallel directions, and would by their authority induce successive Governments to reduce with something like reasonable promptitude the settled facts of science to practical application. Dealing with the details of this proposal, he referred to the fact that the very perfection and comparative complexity of modern systems of drainage became also a means of propagating and disseminating infective diseases, and he would place the direcb and undivided responeibility upon some one to see that the network of precautions was always in perfect order. What was to be done with the sewage matter was one of the pressing questions of the day. But better drains would root out typhoid and diphtheria. Another class of maladies was more obscure in their origin; but whatever that might be, it was their present duty to diagnose early, to notify and to isolate effectually, as well as to treat. Great diff. culties would arise here, but the necessity of isolation was beyond question. Over all such matters the County Councils ought to have control. In matters of doubt and difficulty appeal would be made to the larger bodies sitting in the centres, and they again could refer to the head centre of all. He thought such a bead centre should have a seab in the Commone, and he hoped that on either side of the House carefully trained men might be found who would give themselves up to this work, and be put into office over and over again as opportunity offered. When this Utopian scheme was in existence and everyone lived to a hundred years, it might become a question where all were to be stowed away. This fortunately was no concern of theirs, 